Brancker, who had joined him. But out of the slump grew the de Havilland Aircraft Co., Ltd., and after its formation Mr. Holt Thomas retired from any further active part in aviation, though he gave freely from his wide experience to all who approached him for advice.

Mr. Holt Thomas always took a keen interest in the activities of the Royal Aeronautical Society and served on the Finance Committee for some years. By his death aviation has lost a man who was a genius in his way, a man who saw, as few others have seen, what the future holds for aircraft.

\title{
Richard Elwood Bissell
}

A victim of the Cleveland Clinic disaster which took a toll of over one hundred lives, Richard Elwood Bissell, chief engineer of Thompson Products, Inc., Cleveland, died suddenly May i 5 th, I929, at the age of 37 years.

Richard Elwood Bissell was born at Milford, Michigan, September 4th, I892, and graduated with a degree of Bachelor of Science in I9r3. The following year he received a Master of Science degree from the University of Michigan. In 1927 an honorary degree in metallurgical engineering was conferred upon him by Michigan State College in recognition of contributions he had made to automobile progress. He went with Thompson Products, Inc., ten years ago as head of the metallurgical department, and was made chief engineer last October.

Richard Elwood Bissell was a member of the Society of Automotive Engineers, and an Associate of the Society.

\section{Lieut.-Colonel Sir Alan Burgoyne}

Sir Alan Burgoyne joined the Society in 1917 , and was a Member of Council from I9i 8-1920.

Sir Alan Burgoyne, who was born on September 3 oth, i 880 , was a man of wide interests and took a particular interest in the Navy and the Air Force. For some years he was Hon. Treasurer of the Navy League and founded and edited the Naval League Annual. From I9I6-I9I8 he was Hon. Secretary of the Parliamentary Air Committee, and Treasurer 1919-20.

\section{H. G. Locell}

Mr. H. G. Locell was a Founder Member of the Society, and one of its most enthusiastic supporters.

\section{Captain King Paton}

Captain King Paton was elected an Associate Fellow of the Society in 1919, and during the ten years he was a member he took the keenest possible interest. in the Society.

\section{Pilot Officer Walter Patrick Dillon Bennett}

Pilot Officer W. P. D. Bennett, who became a Student Member of the Society in February, 1929, died as the result of an accident near Boreham Wood, Hertfordshire, to a D.H.6o. Pilot Officer Bennett was on the Reserve of Air Force Officers and at the time of the accident he was the sole occupant of the machine.

\section{Wing-Commander John Dunville}

Wing Comdr. John Dunville, C.B.E., R.A.F., who was a Founder Member of the Society, died on June Ioth, 1929. Wing Comdr. Dunville will always be remembered by a very wide circle of friends for his enthusiastic and practical support of aviation during its pioneering days. He made his first flight in a balloon in I 906 with the late the Hon. Charles Rolls, and from then onwards was a 